The four articles presented in this Forum deal in one way or another with the attitudes of local officials, and in one case residents, toward the COGs movement in urban areas located in three states and one bi-state region. The results of over 340 interviews, referenda in three suburban municipalities, and other research are included. The findings concerning attitudes and functions are not unrelated to the Marando article and in some ways support the hypotheses presented therein. Professor Morgan outlines the experience of the Association of Central Oklahoma Governments. Mr. Barnes summarizes some of the results of an extensive study of the twenty-three Texas COGs. Professor Wikstrom presents the results of a survey of public officials, managers, and party chairmen in three urban areas in Connecticut. My own contribution is a brief description of the Kansas City, Missouri-Kansas attempt to establish a functioning regional council.

\title{
Attitudes Among Local Officials Toward A Council of Governments: The Oklahoma City Situation
}

\author{
DAVID R. MORGAN \\ Department of Political Science, University of Oklahoma
}

The Oklahoma City area council of governments, created in July 1966, has been put to some unusual tests of political approbation in its brief existence. ${ }^{1}$ Created by three counties and fifteen cities, representing 90 per cent of the area population, the Association of Central Oklahoma Governments (ACOG) has been the object of referenda in three separate communities since its inception.

All three communities are bedroom suburbs with widely varying social status and history. Two of the elections are characterized by very low voter turnout and voter approval of ACOG membership. The basic issue varied somewhat from one community to the next. Yukon is an older agricultural town engulfed by urban expansion. Its population has tripled in the past decade and it has become a community of modest priced homes whose residents work in nearby industrial and government installations lo-

Appreciation is expressed to Harvey William Seward, II, for his assistance with this study.

1For a discussion of the Oklahoma City COG development see Robert M. Tinstman, "ACOG - An Experiment in Intergovernmental Relations," 1 Midwest Journal of Public Administration (February, 1967), pp. 6-10. 
cated in the central city. The mayor and city council opposed ACOG membership when it was established and put the issue to the voters in the 1967 municipal election. The local newspaper supported ACOG for fear of losing federal funds. The mayor and a strong foe of ACOG on the city council were defeated for reelection and membership in ACOG was approved by a 67 per cent majority.

In 1968 Moore, Oklahoma, asked the voters whether or not they should retain membership. Moore, a city of about 18,600, is one of the fastest growing municipalities in the nation and is almost entirely residential. It is composed of blue collar workers and lower level civil servants 1esiding in low-priced housing. ACOG membership did not become a major issue even though the mayor expressed serious reservations about the continuation of membership and the ultimate purposes of ACOG. In a light vote the residents of Moore decided to retain ACOG membership by a 64 per cent majority.

In the same year, Nichols Hills, the wealthiest and most exclusive area suburb, voted by a 56 per cent majority to retain ACOG membership. Opposition to participation in ACOG came from a small group of right-wing ideologues who accused the organization of seeking to destroy local government and of fostering dominance by the central city and the federal government: They tried to capitalize on antipathy toward urban renewal and public housing. The city council made a surprisingly spirited defense of its membership on the council of governments.

Despite these rather unusual instances of public involvement in the matter of COG membership, it seems unlikely that a council of governments will attract continuous or extensive public interest except in very special cases. ${ }^{2}$ Since such organizations enjoy a rather low public profile, the political underpinning so essential for COG effectiveness must come from the local public officials who represent its constituent members. In only one of the three instances where public balloting occurred was the vote a result of strictly public pressure. In the other two communities, the opposition to ACOG which culminated in a referenda vote was instigated directly by elected officials. Thus, the attitudes of elected and appointed municipal office-holders toward a council of governments would appear to be of critical importance in determining the ultimate success or failure of this approach to metropolitan problems.

${ }^{2}$ An opinion survey among five Oklahoma City suburbs about 18 months following the creation of ACOG revealed that only 24 per cent of the respondents $(N=223)$ knew of the existence of a council of governments, and only eight per cent could identify it by name. David R. Morgan, "Suburban Differentiation and Metropolitan Political Integration" (unpublished Ph. D. Dissertation, University of Oklahoma, 1969). 
In the summer of 1969 a mailed questionnaire was sent to every mayor, council member and city manager of the 21 cities with over 1,000 population in the Oklahoma City metropolitan area, including the $18 \mathrm{mem}$ bers of ACOG. Replies were received from 90 of 130 officials for a 69 per cent return.

Without getting involved in a detailed analysis of the survey, it was found that two-thirds of those responding were "reasonably well satisfied" with the way ACOG was set up and operating. However, a fairly sizeable minority (23.3 per cent) were either not too satisfied or completely dissatisfied with the current status of ACOG. While few are ecstatic over ACOG, there is widespread agreement over the organization's current scope cf operation. An interesting question still remains, however, as to what kind of political acceptability might be forthcoming if efforts were made to alter the present nature and purpose of ACOG. One question attempted to probe how these office-holders might feel toward the possibility of ACOG developing into a real metropolitan government with each community still retaining its separate identity. Only 19 per cent responded favorably with the overwhelming majority, 71 per cent, in opposition. Those opposing the idea of metropolitan government mentioned such things as loss of local autonomy, control, or identity, and fear of of increased taxes. ${ }^{3}$ Those in support thought it might bring about greater efficiency and economy in the provision of governmental services, cooperation, and possibly lower taxes for the area. As an additional step, respondents were asked,

If you became convinced that an areawide government (with your city retaining its separate identity) would be more efficient and help keep local taxes down, would you favor it?

The replies, in contrast to the previous question, suggest majority support, 55 per cent, for this highly qualified version. ${ }^{4}$

The views of local public officials in the Oklahoma City area toward the current and possible future status of the local council of governments might be summarized as follows: After three years of operation, ACOG appears to have won the endorsement of a substantial majority of the mayors, council members, and city managers in the area. At the same time,

${ }^{3}$ See Advisory Commission on Intergovernmental Relations, Factors Affecting Voter Reactions to Governmental Reorganization in Metropolitan Areas (Washington, 1962) : Scott Greer, Metropolitics: A Study of Political Culture (New York: John Wiley, 1963) ; and Thomas M. Scott, "Metropolitan Governmental Reorganization Proposals," 21 Western Political Quarterly (1968), pp. 252-61.

4The most comprehensive study of local attitudes toward metropolitan governmental reorganization is Amos H. Hawley and Basil G. Zimmer, The Metropolitan Community: Its People and Government (Beverly Hills, California: Sage, 1970). 
these officials are not likely to countenance any effort to transform the present voluntary council structure into something approaching a genuine metropolitan government. Yet, in principle, with the proper safeguards and assurance, they might endorse something a bit more forceful than that which currently exists. Of course, when specific proposals for change are advanced it is far easier to find objections than when one is merely considering a new concept in the abstract. In conclusion, as long as the Association of Central Oklahoma Governments adheres to its fairly limited role of general planning, coordination and federal grant surveillance for the metropolitan area, it seems likely that political support from those who officially represent its constituent members will be forthcoming.

\title{
Experience in Texas
}

\author{
PHILIP W. BARNES \\ Research Associate, Institute of Public Affairs \\ Lyndon B. Johnson School of Public Affairs \\ University of Texas at Austin
}

In Texas, attitudes towards councils of governments are varied. The "average" citizen is unaware generally of regional organization. Few Texas COGs have undertaken highly visible programs or those of a controversial nature. Nonetheless, among certain publics forming COG constituencies, regional organizations and their programs are the subjects of widening political dialogue. At this point in time, it is the "official" and "influential" publics who are debating regional solutions for urban problems." COGs have increased their political legitimacy among these publics, and this is fundamental. If COGs are to contribute substantially to the solution of urban problems, they must have the authority to regulate the distribution of selected public resources. Accordingly, they must have the wherewithal to withstand broadly based, controversial political debate. Such strength depends, in part, on the acceptance of regional councils as legitimate institutions of modern government. In the following narrative, a profile of COG development in Texas is presented along with factors relating to the political legitimacy of the regional council movement.

\section{Texas COGs: A Profile}

The regional council movement began in Texas in 1966. Pressure for federal funds led local officials to form COGs or regional planning

1For a discussion of the various publics comprising COG constituencies, see the author's Metropolitan Coalitions: A Study of Councils of Governments in Texas (Aus. tin: Institute of Public Affairs, The University of Texas, 1969), pp. 77-81. 